\title{
Genetic monitoring of the endangered Pyrenean desman (Galemys pyrenaicus) in the Aude River, France
}

\author{
François Gillet ${ }^{1,2,3, *}$, Bruno Le Roux ${ }^{4}$, Frédéric Blanc ${ }^{3}$, Aurélie Bodo ${ }^{4}$, Christine \\ Fournier-Chambrillon ${ }^{5}$, Pascal Fournier ${ }^{5}$, Frédérick Jacob ${ }^{6}$, Vincent Lacaze ${ }^{7}$, \\ Mélanie Némoz ${ }^{3}$, Stéphane Aulagnier ${ }^{2} \&$ Johan R. Michaux ${ }^{1,8}$
}

${ }^{1}$ Laboratoire de Biologie Evolutive, Unité de Génétique de la Conservation, Université de Liège, Institut de Botanique B22, Quartier Vallée 1, Chemin de la Vallée 4, 4000 Liège, Belgium.

2 Comportement et Ecologie de la Faune Sauvage (CEFS), Institut National de la Recherche Agronomique, 24 Chemin de Borde Rouge, Auzeville, CS 52627, 31326 Castanet-Tolosan Cedex, France.

${ }^{3}$ Conservatoire d'Espaces Naturels de Midi-Pyrénées, 75 voie du Toec, BP 57611, 31076 Toulouse Cedex 3, France

${ }^{4}$ Fédération Aude Claire, 32 Rue des Augustins, 11300 Limoux, France.

${ }^{5}$ Groupe de Recherche et d'Etudes pour la Gestion de l'Environnement (GREGE), Route de Préchac, 33730 Villandraut, France.

${ }^{6}$ EDF, Centre d'Ingénierie Hydraulique, Savoie Technolac, 73373 Le Bourget du Lac, France.

Association des Naturalistes d'Ariège, Vidallac, 09240 Alzen, France.

${ }^{8}$ CIRAD, Agirs Unit, TA C- 22/E- Campus international de Baillarguet, 34398 Montpellier Cedex 5, France.

Corresponding author: f.gillet@hotmail.com; f.gillet@alumni.ulg.ac.be

\begin{abstract}
The Pyrenean desman (Galemys pyrenaicus) is a small semi-aquatic mammal endemic to the Pyrenean Mountains and the northern half of the Iberian Peninsula. This species is currently considered as vulnerable in the IUCN Red List and has been suffering from habitat loss and fragmentation for decades but little is known about the impact of water flow modifications induced by hydroelectric power plants. In order to address this issue we monitored Pyrenean desman individuals living in a harnessed section of the Aude River, by genotyping both faeces samples and hair of live-trapped animals. During a three-year study (2011-2013), a total of 39 individuals were identified using 24 microsatellite loci, 28 from faeces and 11 from trapped animals. Several long distance movements were evidenced up to at least $15 \mathrm{~km}$, a distance that has never previously been reported. These movements might be related to modifications of the river bed caused by very high water flows that occurred during the repair of the Nentilla hydroelectric plant. The local population density suggests that the Aude River provides suitable habitat for the Pyrenean desman, and preservation of this habitat should be a priority for the conservation of this species.
\end{abstract}

KEY WORDS: conservation, Galemys pyrenaicus, genetic, microsatellites, monitoring

\section{INTRODUCTION}

The Pyrenean desman Galemys pyrenaicus (Geoffroy St. Hilaire, 1811) (Chordata, Mammalia) is a small semi-aquatic mammal endemic to the Pyrenean Mountains and the northern half of the Iberian Peninsula where it lives in mountain streams of cold and welloxygenated flowing waters (NORES et al., 2007). This species is considered as vulnerable in the IUCN Red List (FERNANDES et al., 2008) and its ecology and biology are poorly known, notably because of its elusive behaviour and its primarily nocturnal activity (STONE, 1987a; BERTRAND, 1994). However, scientists agree that this species, like other species living in mountain streams, has been suffering from fragmentation and habitat loss, due to the increase of human impact on nature. An example of the human impact on rivers is the construction and operation of hydroelectric power plants. These can lead to physical and biotic modifications and they can alter both hydrologic and thermal regimes, impacting on the resources of benthonic larvae 
of macro-invertebrates (QUEIROZ et al., 1992; CÉRÉGHINO \& LAVANDIER, 1997). Although little information is available for the Pyrenean desman, these detrimental effects have been studied on other mammals and birds, and highlighted by various authors (NILSSON \& DYNESIUS, 1994; D'AMICO et al., 2000). In France, the Aude River has been deeply impacted by the hydroelectric plant of Nentilla, and particularly by its recent repair, which induced modifications of water flows. The monitoring of Pyrenean desmans living in the section of the river downstream from the hydroelectric plant was therefore an opportunity to evaluate the potential impacts of these modifications on this species.

The presence of the Pyrenean desman can be essentially detected by two methods: faeces sampling and live-trapping. These were tested and compared in previous studies (NORES et al., 1998; GonZÁLEZ-ESTEBAN et al., 2003). While live-trapping is onerous to implement and potentially a risk for the species, faeces sampling is non-invasive but should be undertaken with foresight. Specifically, some mistakes can easily occur when collecting samples. Indeed, the Pyrenean desman shares its habitat and diet with other semi-aquatic vertebrate species, such as the water shrew (Neomys fodiens) and the white-throated dipper (Cinclus cinclus), and therefore faeces can be confounded when they are not fresh or have been in contact with water. However, a recent reliable and non-invasive method was developed to easily distinguish faeces of the Pyrenean desman from these other species (GILLET et al., 2015a). Moreover, genotyping of faeces with microsatellite markers can be used to survey populations or to monitor individuals of rare mammal species (TABERLET et al., 1997; EGGERT et al., 2003; MONDOL et al., 2009a, 2009b). Therefore, we monitored individuals of Pyrenean desmans living in the section of the Aude River impacted by the Nentilla hydroelectric plant by combining the genotyping of faeces samples and hairs of livetrapped animals.

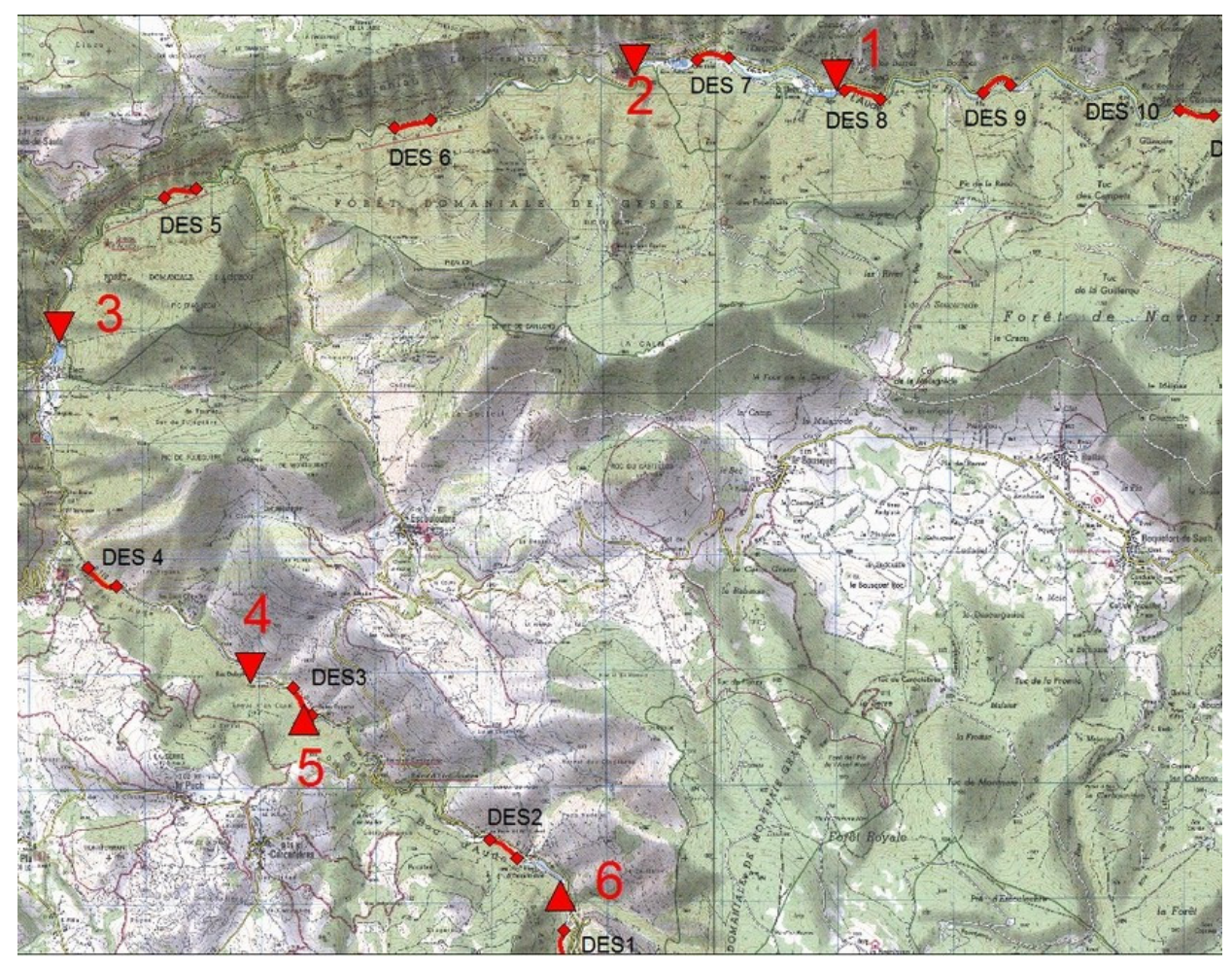

Fig. 1. - Map of the study area showing the ten river segments (DES1 to DES10) and different obstacles (red arrows) along the Aude river. All obstacles are water intakes of different heights: $3 \mathrm{~m}, 1 \mathrm{~m}, 9 \mathrm{~m}, 1 \mathrm{~m}, 75 \mathrm{~cm}$ and $2 \mathrm{~m}$ for obstacles 1 to 6 , respectively. 


\section{MATERIAL AND METHODS}

\section{Sampling protocol}

Three campaigns of faeces sampling were conducted: between January and April 2011, between March and July 2012 and between July and August 2013 respectively. The dates were not fixed since faeces sampling was dependent on the weather and the river flows. Along 20 $\mathrm{km}$ of the Aude River, ten $300 \mathrm{~m}$-long segments were surveyed twice a year (Figure 1). These segments of the Aude River were situated in the Department of the same name, in the eastern part of the French distribution of the Pyrenean desman. The mean elevation of these segments was $693 \mathrm{~m}$ with the highest segment being DES $1(990 \mathrm{~m})$ and the lowest DES 10 (455 m) (Figure 1). Banks of the river mostly consisted of trees, shrubs and bushes.

During the first campaign, each faeces sample was collected in a small tube $(1.5 \mathrm{ml})$ fitted in a larger one containing silica-gel. During the second and third campaigns, faeces were collected in tubes $(1.5 \mathrm{ml})$ containing absolute ethanol. The geographic position of each faeces was recorded on a GPS device.

Additionally, trapping sessions were conducted in three segments (DES3, DES7 and DES9, Figure 1) during six nights (two nights per segment) in September 2011, 2012 and 2013. Each trapping segment was extended to $900 \mathrm{~m}$ long (or less depending on the accessibility to the river) and was divided in sub-segments of $300 \mathrm{~m}$ long (or less). Eighteen traps, formed by two modified fish-traps hooked to each other, were set up in the most homogeneous way, without fixing arbitrary distances between them. Traps were laid where the strongest water flow occurred, in the river or near the banks, with the entrance facing the water flow and the rear portion out of the water to form a repository for the trapped Pyrenean desman. They were laid late in the day (18:00 local time) and removed early in the next morning (4:00 local time). Traps were checked every hour. Captured Pyrenean desmans were weighed, sexed, eventually marked with varnish on claws of a hind leg or with a transponder, and a hair sample taken that was immediately placed in a $1.5 \mathrm{ml}$ tube containing absolute ethanol. Hair samples were collected under licenses from the French Government: ${ }^{\circ}$ 2011221-0004 for Aude Department and $n^{\circ}$ 2011-INT/01 for Ariège Department. Animals were then released at the site of capture. A post-trapping sampling of faeces was achieved each time in the three segments.

\section{Sampling and DNA extraction}

Genomic DNA from hair and faeces samples preserved in ethanol was extracted using the QIAmp DNA Micro Kit (Qiagen Inc., Hilden, Germany) and the Stool Mini Kit (Qiagen Inc., Hilden, Germany), respectively, all following the manufacturer's instructions. To avoid any cross contamination, DNA extractions from faeces samples were conducted in a separated room with a UV-sterilised platform where no Pyrenean desman tissue samples were previously treated.

\section{DNA amplification}

Identification of Pyrenean desman from faeces was ascertained by amplification of a small cytochrome $b$ fragment, as described in GILLET et al. (2015a). Then hair samples and faeces were genotyped at 24 variable microsatellite loci (Table 1). Microsatellites were distributed in five Multiplex kits based on size limitations. PCRs were carried out in $10 \mu \mathrm{l}$ volume containing 0.15 of each $20 \mu \mathrm{M}$ primers, $7.5 \mu 1$ of Multiplex PCR kit (Qiagen Inc., Hilden, Germany) and $5 \mu 1$ of DNA. Amplifications were performed in a thermal cycler VWR Unocycler using one activation step at $95^{\circ} \mathrm{C}$ for $15 \mathrm{~min}$ followed by 35 cycles (denaturation at $94^{\circ} \mathrm{C}$ for $30 \mathrm{~s}$, annealing at $57^{\circ} \mathrm{C}$ for $90 \mathrm{~s}$, extension at $72^{\circ} \mathrm{C}$ for $60 \mathrm{~s}$ ) and final extension step at $72^{\circ} \mathrm{C}$ for $30 \mathrm{~min}$. Amplified DNA was analyzed for length variations on an ABI 3700 sequencer using GeneScan 500 LIZ ${ }^{\circledR}$ 


\section{TABLE 1}

Genotyping of 24 microsatellite loci in Pyrenean desman of the Aude River (France). Null allele frequency (NAF), rates of positive PCR (PCR+), allelic dropout (ADO) and false allele (FA) for each locus.

\begin{tabular}{|c|c|c|c|c|c|c|c|}
\hline Locus & $\boldsymbol{H}_{\boldsymbol{E}}$ & $\boldsymbol{H}_{\boldsymbol{O}}$ & No. alleles & NAF & PCR+ & ADO & FA \\
\hline GpyrGS06 & 0.10 & 0.06 & 2 & 0.13 & 0.77 & 0.00 & 0.009 \\
GpyrGS07 & 0.04 & 0.03 & 2 & 0.00 & 0.74 & 0.00 & 0.000 \\
GpyrGS10 & 0.31 & 0.31 & 4 & 0.00 & 0.77 & 0.06 & 0.013 \\
GpyrGS11 & 0.17 & 0.17 & 3 & 0.02 & 0.78 & 0.07 & 0.000 \\
GpyrGS12 & 0.10 & 0.05 & 2 & 0.00 & 0.82 & 0.00 & 0.009 \\
GpyrGS13 & 0.13 & 0.03 & 2 & 0.10 & 0.89 & 0.00 & 0.000 \\
GpyrGS18 & 0.12 & 0.10 & 2 & 0.00 & 0.80 & 0.00 & 0.000 \\
GpyrGS20 & 0.57 & 0.38 & 4 & 0.00 & 0.74 & 0.00 & 0.014 \\
GpyrGS22 & 0.29 & 0.24 & 3 & 0.07 & 0.82 & 0.21 & 0.000 \\
GpyrGS23 & 0.43 & 0.48 & 3 & 0.00 & 0.79 & 0.05 & 0.000 \\
GpyrGS30 & 0.13 & 0.07 & 2 & 0.00 & 0.77 & 0.00 & 0.000 \\
GpyrGS32 & 0.62 & 0.41 & 3 & 0.00 & 0.81 & 0.17 & 0.000 \\
GpyrGS33 & 0.29 & 0.17 & 2 & 0.20 & 0.74 & 0.10 & 0.000 \\
GpyrGS34 & 0.38 & 0.41 & 3 & 0.00 & 0.79 & 0.26 & 0.000 \\
GpyrGS41 & 0.07 & 0.07 & 2 & 0.00 & 0.92 & 0.21 & 0.000 \\
GpyrGS46 & 0.05 & 0.05 & 2 & 0.12 & 0.87 & 0.00 & 0.000 \\
GpyrGS47 & 0.07 & 0.03 & 2 & 0.08 & 0.87 & 0.00 & 0.000 \\
GpyrGS53 & 0.03 & 0.03 & 2 & 0.16 & 0.87 & 0.00 & 0.000 \\
GpyrGS55 & 0.08 & 0.03 & 2 & 0.00 & 0.83 & 0.00 & 0.000 \\
GpyrGS74 & 0.04 & 0.03 & 2 & 0.09 & 0.84 & 0.00 & 0.000 \\
GpyrGS75 & 0.06 & 0.06 & 2 & 0.07 & 0.87 & 0.00 & 0.000 \\
GpyrGS80 & 0.12 & 0.09 & 2 & 0.00 & 0.88 & 0.00 & 0.000 \\
GpyrGS82 & 0.49 & 0.21 & 2 & 0.15 & 0.47 & 0.25 & 0.014 \\
GpyrGS94 & 0.07 & 0.07 & 2 & 0.00 & 0.93 & 0.00 & 0.000 \\
\hline
\end{tabular}

size standard and alleles were scored on GENEMAPPER 4.0 (Applied Biosystems).

In order to avoid genotyping errors in our dataset, consensus genotypes had to be constructed for faeces samples. For this, we used a modified multitube PCR approach (TABERLET et al., 1996) and we repeated four times each PCR. We chose to accept scoring alleles if they appeared at least three times out of the four PCRs and we only considered $100 \%$ matches to accept identical genotypes.

\section{Statistical analysis}

Each replicate genotype was compared with the consensus genotype to quantify the error rates; both the construction of the consensus genotype and the quantification of error rates such as false alleles (FA) and allelic dropouts (ADO) were performed using GIMLET v1.3.3 (VALIÈre, 2002). Expected $\left(H_{E}\right)$ and observed $\left(H_{O}\right)$ heterozygosity, as well as the probability of identity among siblings PIDsibs (i.e. the probability that two related individuals have 
the same genotype (WAITS et al., 2001)) were estimated using GIMLET v1.3.3. The HardyWeinberg (HW) equilibrium was tested using the exact test implemented in GENEPOP 4.1.0 (Rousset, 2008). Tests for linkage disequilibrium between loci were performed using GENEPOP 4.1.0 and MICRO-CHECKER 2.2.3 (VAN OOSTERHOUT et al., 2004) was used to estimate the proportion of null alleles (NA).

\section{RESULTS}

A total of 131, 160 and 150 putative faeces of Pyrenean desman were collected in 2011, 2012 and 2013 respectively. In addition, 7, 2 (one new individual and one recapture) and 3 individuals were trapped for the same years, respectively (Table 2). Out of the 441 collected faeces, 267 were assigned to the Pyrenean desman, and one to the white-throated dipper, after sequencing a small cytochrome $b$ fragment. DNA was probably too much degraded in the other faeces or these belonged to other species not targeted by our primers. 204 Pyrenean desman faeces (64, 80 and 60 in 2011, 2012 and 2013 respectively) were genotyped for microsatellite loci (Table 1). The mean $H_{O}$ was 0.15 (ranging from 0.03 to 0.48 ) while the mean $H_{E}$ was 0.20 (ranging from 0.03 to 0.62 ) (Table 1). The number of alleles ranged from 2 to 4 (Table 1). Tests for HWE showed significant deviations for only one locus (GpyrGS13, p-value $=0.001$ ) and no linkage disequilibrium was found after Bonferroni's correction. The mean proportion of positive PCRs was $81 \%$, ranging from $47 \%$ to $93 \%$ among loci and from $39 \%$ to $100 \%$ among samples. The mean Allelic Dropout (ADO) rate was 0.06 , ranging from 0 to 0.26 , and the mean false allele (FA) rate was 0.01 , ranging from 0 to 0.014 (Table 1).

MICRO-CHECKER did not detect any significant bias in our dataset that could be attributed to null alleles (Table 1). A total of 28 additional individuals were identified from faeces with a PID (sibs) of $4.46 \mathrm{e}^{-03}$.
Nineteen individuals were identified in 2011, seven were trapped (four males and three females) and twelve were identified from faeces. Furthermore, two trapped animals were identified again from faeces in the same segments (DES3 and DES9), two and three days after their capture respectively. One individual, identified from faeces, was found $4.8 \mathrm{~km}$ upstream from DES9 (on May 3), in DES6 (on June 9).

Nine new individuals were identified in 2012, one (female) was trapped and eight were identified from faeces. In addition, one individual (female) trapped in 2011 was recaptured in 2012 (Table 2). Two animals identified in 2011 were identified again from faeces collected in 2012. The first one was found $16.2 \mathrm{~km}$ upstream from DES7 (on September 20, 2011), in DES1 (on July 13, 2012). The second was found $17.8 \mathrm{~km}$ upstream from DES9 (on September 20, 2011), in DES2 (on September 7, 2012).

Eleven new individuals were identified in 2013, three (females) were trapped and eight were identified from faeces. One animal identified in 2011 was identified again in 2013 in the same river segment (DES3). One of the three trapped individuals was identified from faeces collected two months before its capture. Finally, the shortterm movement of one individual was evidenced, as it was found $1.6 \mathrm{~km}$ downstream from DES8 (on August 20), in DES9 (on August 28).

The number of individuals identified per river segment and per year is given in Table 1. The river segments DES3, DES7 and DES9 hosted 8, 9 and 11 individuals, respectively. No desman was found in three segments: DES5, DES10 and DES13.

\section{DISCUSSION}

According to our results, the genotyping of the 24 microsatellites proved to be a reliable technique to identify Pyrenean desmans and to implement individual monitoring as several animals were found one or two years after being 


\section{TABLE 2}

Number of collected faeces / number of faeces belonging to the Pyrenean desman / number of genotyped faeces / number of identified individuals of Pyrenean desman (in bold), per river segment and per year in the Aude River (France). Trapping sessions occurred in segments DES3, DES7 and DES9. Numbers in brackets are trapped individuals that are included in the total number of identified individuals. "**" indicates one individual trapped in 2011 that was recaptured in 2012.

\begin{tabular}{|l|c|c|c|c|c|c|c|c|c|c|c|}
\hline & DES1 & DES2 & DES3 & DES4 & DES5 & DES6 & DES7 & DES8 & DES9 & DES10 & Total \\
\hline $\mathbf{2 0 1 1}$ & $3 / 3 / 3 / \mathbf{1}$ & 0 & $\begin{array}{c}14 / 13 / 13 / \mathbf{5} \\
\mathbf{( 1 )}\end{array}$ & 0 & $9 / 0$ & $6 / 0$ & $\begin{array}{c}42 / 16 / 14 / 7 \\
\mathbf{( 3 )}\end{array}$ & $8 / 5 / 5 / 0$ & $\begin{array}{c}42 / 29 / 29 / \mathbf{6} \\
\mathbf{( 3 )}\end{array}$ & $7 / 0$ & 19 \\
\hline $\mathbf{2 0 1 2}$ & $53 / 37 / 37 / \mathbf{2}$ & $38 / 27 / 27 / \mathbf{2}$ & $5 / 3 / 3 / 0$ & $1 / 1 / 1 / 0$ & $14 / 0$ & $11 / 4 / 4 / \mathbf{2}$ & $7 / 4 / 4 / \mathbf{1}$ & $11 / 1 / 1 / 0$ & $\begin{array}{c}6 / 2 / 2 / 3(\mathbf{1}) \\
\left(\mathbf{1}^{*}\right)\end{array}$ & $14 / 1 / 1 / 0$ & 9 \\
\hline $\mathbf{2 0 1 3}$ & $35 / 31 / 8 / 0$ & $35 / 30 / 7 / 0$ & $\begin{array}{c}34 / 16 / 9 / 3 \\
\mathbf{( 1 )}\end{array}$ & $6 / 6 / 6 / \mathbf{1}$ & $6 / 6 / 6 / 0$ & $9 / 9 / 6 / \mathbf{2}$ & $8 / 8 / 6 / \mathbf{1}(\mathbf{1})$ & $6 / 6 / 6 / \mathbf{1}$ & $8 / 8 / 5 / \mathbf{3}(\mathbf{1})$ & $3 / 1 / 1 / 0$ & 11 \\
\hline Total & 3 & 2 & $8(2)$ & 1 & & 4 & $9(4)$ & 1 & $11(5)$ & 0 & 39 \\
\hline
\end{tabular}

first identified. However, the results of this technique are highly dependent on the freshness, and the size of faeces, at the time of collecting. Indeed, Pyrenean desman faeces are generally small (10 to $15 \mathrm{~mm}$ long and 4 to $8 \mathrm{~mm}$ wide, (BERTRAND 1993)) and the contained DNA degrades quickly in nature due to water and UV radiation. Genotyping faeces can also be seen as complementary to the trapping of individuals as it is without risk of harm to the animals and requires less field workforce. On the other hand, the trapping of Pyrenean desmans can provide more information on the individuals such as their sex, size, body mass, etc.

The three, yearly sessions of faeces sampling and trapping successfully led to the identification of 39 individuals along the $20 \mathrm{~km}$ stretch of the Aude River. However, the number of individuals identified from faeces could be overestimated due to error rates. Eleven individuals were trapped: 4 males and 7 females. The other 28 individuals identified from faeces could not be sexed and therefore the sex-ratio could hardly be representative of the population. The highest number in a $300 \mathrm{~m}$ segment of river was found in 2011 in DES7 $(n=7)$, followed by DES9 $(n=$ $6)$ and DES3 $(n=5)$. However, these results could be impacted by the time of sampling and the water flows. Moreover, all collected faeces could not be genotyped and therefore the number of animals could be underestimated in other segments and/or years. As the length of the sampled river segments is within the order of magnitude of reported home ranges (STONE, 1987b; Silva, 2001; GISBERT \& GARCIÁ-PEREA, 2004; MELERO et al., 2012), these high numbers of Pyrenean desman per segment could support the results of MELERO et al. (2012, 2014) concerning the social behaviour of this species and the overlapping of home ranges.

Movements of four individuals were evidenced during this study as they were found at distances of $1.6 \mathrm{~km}, 4.8 \mathrm{~km}, 16.2 \mathrm{~km}$ and $17.8 \mathrm{~km}$, eight days, one month, ten months and one year later, respectively. Although several distances between rest sites have been reported (MELERO et al., 2012), long-distance movements have never been recorded before for the Pyrenean desman. STONE (1987a) showed that populations of Pyrenean desman were composed of sedentary and erratic individuals, the latter being mainly juveniles and solitary adults. As the four individuals mentioned above were identified from faeces, we have no information on their sex or age. These movements could be related to modifications of the river during the repair works. Indeed, from November 2011, very high water flows have been observed downstream from the segment 
DES2 and they have profoundly impacted the river bed. Therefore some individuals may have moved upstream to find more suitable habitat, notably in the less impacted segments DES1 and DES2. This also means that the Pyrenean desman can disperse when its habitat is impoverished and that its response can be quick. In addition, individuals who moved over long distances should have encountered hydraulic plants or dams on their way (Figure 1). This could confirm that the Pyrenean desman is able to cross over such obstacles, as it was previously suggested (CHORA \& QUARESMA, 2001).

\section{CONCLUSION}

This study confirms the genotyping of faeces as a reliable method to identify Pyrenean desmans, in addition to, or as a substitute for trapping, in order to perform individual monitoring. However, sexing the animals from faeces should be investigated, while ageing will remain impossible, making difficult direct studies of population dynamics. Several movements of individuals evidenced that Pyrenean desmans can travel long distances. This new and unexpected finding is particularly interesting in terms of conservation. However, a longer term study is required to investigate the reason for this dispersal. Finally, the observed numbers present in short segments demonstrate that the Aude River, and its basin, are suitable habitat for the Pyrenean desman, and emphasise that particular attention should be paid to this river in regard to conservation of this species.

\section{ACKNOWLEDGMENTS}

We deeply thank the Fédération Aude Claire who collected faeces samples. We are grateful to the following people who helped us during the trapping sessions and particularly: Alain, Bertrand, Olivier Billard, Patrick Bodo, Cathie Boléat, Anaïs Charbonnel, Sarah Perré, Gabrielle Rosenau. This study is part of the "Plan National d'Actions en faveur du
Desman des Pyrénées" and the LIFE+ Desman (LIFE13NAT/FR/000092) which are coordinated by the Conservatoire d'Espaces Naturels de Midi-Pyrénées (CEN-MP) and are financially supported by the following structures: European Union Funding Network (ERDF and LIFE+), Agence de l'eau Adour-Garonne, Agence de l'eau Rhône-Méditerranée-Corse, DREAL Aquitaine, Midi-Pyrénées, and LanguedocRoussillon, Conseil Régional Aquitaine, MidiPyrénées and Languedoc-Roussillon, Conseil Général des Pyrénées-Atlantiques, de l'Aude et des Pyrénées-Orientales, EDF, SHEM, Patagonia, Parc National des Pyrénées, ANRT (Association Nationale de la Recherche et de la Technologie). F. Gillet is supported by a French research fellowship provided by the ANRT (CIFRE N²011/1571).

\section{REFERENCES}

Bertrand A (1993). Découvrir le Desman des Pyrénées, Ed. A.N.A., 32 p.

BERTRAND A (1994). Répartition géographique et écologie alimentaire de desman des pyrénées $\mathrm{G}$. pyrenaicus dans les Pyrénées françaises. Diplôme Universitaire de Recherche, Toulouse, 217p.

CÉRÉGHINO R \& LAVANDIER P (1997). Influence des éclusées hydroélectriques sur la distribution et le développement larvaire des Diptères Simuliidae d'une rivière de moyenne montagne. Comptes Rendus 1'Académie des Sciences. - Series. III Sciences de la Vie, 320: 329-338 http://dx.doi. org/10.1016/S0764-4469(97)82775-8

CHORA SC \& QUARESMA CM (2001). Desman, Galemys pyrenaicus, Goeffroy 1811: spatial use patterns and ability to transpose the Fráguas small hydro (Paiva river, Douro Basin). 4èmes rencontres sur le Desman des Pyrénées, 18-20 octobre 2001, Moulis: 6 p.

D'Amico F, Manel S, Mouches C \& Ormerod SJ (2000). River birds in regulated rivers : cost or benefit? Verhandlungen des Internationalen Verein Limnologie, 27: 167-170.

EGGERT LS, EGGERT JA \& WOODRUFF DS (2003). Estimating population sizes for elusive animals: the forest elephants of Kakum National Park, Ghana. Molecular Ecology, 12: 1389-1402. http:// dx.doi.org/10.1046/j.1365-294X.2003.01822.x 
FERnANDEs M, Herrero J, Aulagnier S \& AMORI G (2008). Galemys pyrenaicus. IUCN Red List Threat. Species. Version 2013.2.

Gillet F, CABria MT, Némoz M, Blanc F, FOURNIER-CHAMBrillon C, SOURP E, VIALNovella C, Aulagnier S \& MichauX JR (2015a). PCR-RFLP identification of the endangered Pyrenean desman, Galemys pyrenaicus (Soricomorpha, Talpidae), based on faecal DNA. Mammalia, 79: 473-477. http:// dx.doi.org/10.1515/mammalia-2014-0093

Gillet F, CABria MT, Blanc F, FournierChambrillon C, NÉmOZ M, Sourp E, VialNovella C, AUlagnier S \& MichauX JR (2015b, in prep.). Isolation, characterization and PCR multiplexing of polymorphic microsatellite markers in the endangered Pyrenean desman, Galemys pyrenaicus. Conservation Genetics Resources.

Gisbert J \& GARCiÁ-Perea R (2004). Estudio cuantitativo sobre la población de Desmán Ibérico en el valle del Ambroz y Topillo de Cabrera en el norte de Extremadura. Junta de Extremadura, 400 pp.

GonzÁlez-Esteban J, Villate I \& CAstien E (2003). A comparison of methodologies used in the detection of the Pyrenean desman Galemys pyrenaicus (E. Geoffroy, 1811). Mammalian Biology, 68: 387-390.

Melero Y, AyMerich P, LuQue-Larena JJ \& GosÀlbeZ J (2012). New insights into social and space use behaviour of the endangered Pyrenean desman (Galemys pyrenaicus). European Journal of Wildlife Research, 58: 185-193. http://dx.doi. org/10.1007/s10344-011-0561-7

MELERo Y, Aymerich P, SANTUlli G \& GosÀlbeZ $J$ (2014). Activity and space patterns of Pyrenean desman (Galemys pyrenaicus) suggest nonaggressive and non-territorial behaviour. Eur. J. Wildl. Res., 60: 707-715. dhttp://dx.doi. org/10.1007/s10344-014-0838-8

MONDOL S, KARANTH KU, KUMAR NS, GOPALASWAMY AM, ANDHERIA A \& RAMAKRISHNAN U (2009a). Evaluation of noninvasive genetic sampling methods for estimating tiger population size. Biological Conservation, 142: 2350-2360. http://dx.doi.org/10.1016/j. biocon.2009.05.014

Mondol S, Navya R, Athreya V, Sunagar K, SELVARAJ VM \& RAMAKRISHNAN U (2009b). A panel of microsatellites to individually identify leopards and its application to leopard monitoring in human dominated landscapes. Bmc Genetics, 10: $79 \mathrm{http} / / / \mathrm{dx}$.doi.org/10.1186/1471-2156-10-79

NILSSON C \& DYNESIUS M (1994). Ecological effects of river regulation on mammals and birds: Areview. Regulated Rivers: Research \&Management, 9: 45-53. http://dx.doi.org/10.1002/rrr.3450090105

Nores C, OJedA F, RuANo A, Villate I, GONZALEZ J, CANO JM \& GARCIA E (1998). Estimating the population density of Galemys pyrenaicus in four Spanish rivers. Journal of Zoology, 246: 454-457.

Nores C, QueIroz AI \& Gisbert J (2007). Galemys pyrenaicus (E. Geoffroy Saint-Hilaire, 1811)., in: Palomo, L., Gisbert, J., Blanco, J. (Eds.), Atlas Y Libro Rojo de Los Mamíferos Terrestres de España. Madrid: Dirección General para la Biodiversidad - SECEM - SECEMU, pp. 92-98.

Queiroz AI, Alves MH \& Almada V (1992). The small hydroplants: predicted impacts on the Pyrenean desman populations (Galemys pyrenaicus. Geoffroy). In: Proceeding Meeting on the Pyrenean Desman. Lisboa, pp. 69-77.

Rousset F (2008). genepop'007: a complete re-implementation of the genepop software for Windows and Linux. Mol. Ecol. Resour, 8: $103-6 . \quad$ http://dx.doi.org/10.1111/j.14718286.2007.01931.x

SILVA E (2001). Estudo da capacidade de transposição de obstáculo do rio Ardena pela toupeira de água (Galemys pyrenaicus). Relatório de Estágio para obtenção da licenciatura em Biologia, pela Faculdade de Ciências da Universidade do Porto.

STONE RD (1987a). The activity pattern of the Pyrenean desman (Galemys pyrenaicus) (Insectivora: Talpidae), as determined under natural condition. Journal of Zoology, 213: 95106.

STONE RD (1987b). The social ecology of the Pyrenean desman as revealed by radiotracking. Journal of Zoology, 212: 117-129.

TABerlet P, CAMARRA JJ, Griffin S, Uhres E, Hanotte O, Waits LP, Dubois Paganon C, BURKE T \& BOUvET J (1997). Noninvasive genetic tracking of the endangered Pyrenean brown bear population. Molecular Ecology, 6: 869-876.

TABerlet P, Griffin S, GoOsSens B, Questiau S, Manceau V, Escaravage N, Waits LP \& BOUVET J (1996). Reliable genotyping of samples with very low DNA quantities using PCR. Nucleic Acids Research, 24: 3189-94. 
VALIÈRE N (2002). GIMLET: a computer program for analysing genetic individual identification data. Molecular Ecology Notes, 2: 377-379. http:// dx.doi.org/10.1046/j.1471-8286.2002.00228.x

VAN OOSTERHOUT C, HUTCHINSON WF, WiLLS DPM \& SHIPLEY P (2004). Micro-Checker: Software for Identifying and Correcting Genotyping Errors in Microsatellite Data. Molecular Ecology Notes, 4: 535-538. http://dx.doi/org0.1111/j.14718286.2004.00684.x

WAits L.P., Luikart G., TABERLET P. (2001). Estimating the probability of identity among genotypes in natural populations: cautions and guidelines. Molecular Ecology. 10, 249-56.

Received: September 9th, 2015

Accepted: January 18th, 2016

Branch editor: Peter Galbusera 